\title{
Functionalized carbon nanotubes: biomedical applications
}

This article was published in the following Dove Press journal:

International Journal of Nanomedicine

8 October 2012

Number of times this article has been viewed

\author{
Sandhya Vardharajula' \\ Sk Z Ali \\ Pooja M Tiwari' \\ Erdal Eroğlu' \\ Komal Vig' \\ Vida A Dennis' \\ Shree R Singh' \\ 'Center for NanoBiotechnology \\ and Life Sciences Research, Alabama \\ State University, Montgomery, AL, \\ USA; ${ }^{2}$ Department of Microbiology, \\ Osmania University, Hyderabad, India
}

Correspondence: Shree R Singh Department of Microbiology, Alabama State University, 305 Life Science Bldg, 1627 Hall St, Montgomery, AL 36104, USA

$\mathrm{Tel}+\mathrm{I} 3342294598$

Fax +I 3342294955

Email ssingh@alasu.edu

\begin{abstract}
Carbon nanotubes (CNTs) are emerging as novel nanomaterials for various biomedical applications. CNTs can be used to deliver a variety of therapeutic agents, including biomolecules, to the target disease sites. In addition, their unparalleled optical and electrical properties make them excellent candidates for bioimaging and other biomedical applications. However, the high cytotoxicity of CNTs limits their use in humans and many biological systems. The biocompatibility and low cytotoxicity of CNTs are attributed to size, dose, duration, testing systems, and surface functionalization. The functionalization of CNTs improves their solubility and biocompatibility and alters their cellular interaction pathways, resulting in muchreduced cytotoxic effects. Functionalized CNTs are promising novel materials for a variety of biomedical applications. These potential applications are particularly enhanced by their ability to penetrate biological membranes with relatively low cytotoxicity. This review is directed towards the overview of CNTs and their functionalization for biomedical applications with minimal cytotoxicity.
\end{abstract}

Keywords: carbon nanotubes, cytotoxicity, functionalization, biomedical applications

\section{Introduction}

The greatest advantage of nanotechnology lies in its potential to create novel structures with enhanced abilities to translocate through cell membranes, and increased solubilization, stability, and bioavailability of biomolecules, thereby enhancing their delivery efficiency. Nanotechnology offers intriguing opportunities for various applications in biomedical fields, including bioimaging ${ }^{1}$ and targeted delivery of biomacromolecules into cells. ${ }^{2}$ Many strategies have been proposed to functionalize carbon nanotubes (CNTs) with increased solubility for effective use in biomedical applications. ${ }^{3}$ CNTs, hollow cylinders composed of rolled sheets of graphene built from a hexagonal arrangement of $\mathrm{sp}^{2}$-hybridized carbon atoms in nanoscale dimensions, were first introduced by Iijima. ${ }^{4}$ CNTs have unique structures and extravagant mechanical, thermal, magnetic, optical, electrical, surface, and chemical properties, and the combination of these characteristics bestows them with extensive biomedical applications. ${ }^{5,6} \mathrm{CNTs}$ are relatively flexible and interact with the cell membranes and penetrate various biological tissues ${ }^{7-9}$ due to a "snaking effect," 10 hence both the pharmacological ${ }^{11}$ and toxicological ${ }^{12}$ profiles of CNTs have gathered much attention recently. ${ }^{13,14}$ In this review, we have focused on functionalized CNTs (fCNTs) with low/ no cytotoxicity using functionalization processes, which is the fundamental prerequisite for applications of CNTs in biomedicine. The review also focuses on in vitro and 
in vivo toxic effects of various fCNTs as compared to CNTs. Advantages and applications of CNT functionalization methods in reducing the cytotoxicity followed by their in vivo applications as biomaterials in tissue, cells, bone, and blood are also discussed.

\section{Toxicity of carbon nanotubes}

The physicochemical properties of CNTs make them unique and capable of changing the biological or toxicological behavior of living organisms or the environment. CNTs have a highly hydrophobic surface and a nonbiodegradable nature that contributes to their reduced biocompatibility, limiting their biomedical applications, with growing concerns about their chronic toxicity. ${ }^{15}$ With several years of research, CNTs have been shown to have adverse effects. The toxicity of CNTs is attributed to their physicochemical properties, including structure, length and aspect ratio, surface area, degree of aggregation, extent of oxidation, surface topology, bound functional group(s), manufacturing method, concentration, and dose offered to cells or organisms. ${ }^{16-19}$ CNTs can elicit toxicity through membrane damage, DNA damage, oxidative stress, changes in mitochondrial activities, altered intracellular metabolic routes, and protein synthesis. ${ }^{10,20-24}$ The most common mechanisms of CNT cytotoxicity also encompass apoptosis and necrosis. ${ }^{25-27}$ However, CNT cytotoxicity is significantly controversial, with a large number of studies reporting altered toxic responses to CNTs both in vitro and in vivo. ${ }^{10,15,28,29}$

\section{In vitro toxicity studies}

One of the first studies investigating the toxicity of pristine single-walled CNTs (SWCNTs) in human epidermal keratinocytes revealed that exposure to SWCNTs could elevate oxidative stress and reduce cell viability. ${ }^{30}$ Even purified CNTs in pristine form showed cellular toxicity. ${ }^{26,27}$ The cytotoxicity of CNTs has also been related to their structure. ${ }^{15}$ It is reported that multiwalled CNTs (MWCNTs) with larger diameters are more cytotoxic compared to ones with lesser diameters. ${ }^{31}$ At the same time, the cytotoxicity of unmodified SWCNTs was found to be dose- and timedependent. ${ }^{27,32,33}$ Surface modification led to reduced cell death, with non-surface-modified CNTs being more cytotoxic compared to surface-modified CNTs at concentrations of $0.1 \mathrm{mg} / \mathrm{mL}$ and $5 \times 10^{-5} \mu \mathrm{g} / \mathrm{mL}$, respectively. ${ }^{17}$ Similarly, enhanced interaction times resulted in higher amounts of apoptosis in both fCNTs and CNTs, though fCNTs were less apoptotic. ${ }^{34}$ Another study involving HeLa cells treated with increased doses of functionalized SWCNTs and
MWCNTs showed a $50 \%$ reduction in cell number. ${ }^{35}$ In a similar study, human epidermal keratinocytes when treated with $0.00000005-0.05 \mathrm{mg} / \mathrm{mL}$ of 6-aminohexanoic acid-derivatized (AHA)-SWCNTs resulted in diminished cell viability and escalation in the expression of cytokines, demonstrating that greater concentrations of AHA-SWCNTs were cytotoxic. ${ }^{25}$ Similarly, macrophages showed a higher half maximal effective concentration for MWCNTs ${ }^{36}$ compared to human lung epithelial cells (A549). ${ }^{37}$ It has also been shown that the functional group significantly affects cellular toxicity. ${ }^{38}$ SWCNTs functionalized with phenyl- $\mathrm{SO}_{3} \mathrm{H}$ and phenyl- $\mathrm{SO}_{3} \mathrm{Na}$ had no crucial mutilation to the cells in vitro even at high concentrations $(>2 \mathrm{mg} / \mathrm{mL})$, whereas phenyl-(COOH$)_{2}$-SWCNTs manifested toxicity even at low concentrations of $80 \mu \mathrm{g} / \mathrm{mL}$. Thus, there have been numerous reports on in vitro effects of CNTs in various cellular models that have demonstrated that the adverse effects of CNTs are dependent on their size, structure, and the functionalization modules.

\section{In vivo toxicity studies}

In order to investigate further the effects of CNTs in vivo, several studies have been conducted. In one such study, mice intratracheally infused with SWCNT implants developed epithelioid granulomas with interstitial inflammation. ${ }^{39}$ Similarly, undoped MWCNTs induced severe inflammatory responses when compared to nitrogen-doped MWCNTs upon intratracheal administration in mice. ${ }^{40}$ There have been several indications that CNTs cause oral, dermal, pulmonary, and systemic toxicities. ${ }^{41}$ Inhaled SWCNTs have been shown to cause pulmonary toxicity in rats. ${ }^{42}$ Lavaged fluids from CNT-treated mice have shown a dose-dependent increase in inflammation and oxidative stress. ${ }^{43}$ It has also been observed that pristine SWCNTs show increased oxidative stress in liver and lung in a dose-dependent manner; instead relatively persistent stress has been recorded in the spleen even at higher concentration of CNTs. In vitro testing demonstrated that the size and shape of the CNTs affect their entry into the macrophages, resulting in various immune responses. ${ }^{44}$ In a similar study, shorter CNTs showed low toxicity with increased penetration ability for macrophages and phagocytes compared to their longer $(>0.8 \mu \mathrm{m})$ counterparts. $^{45}$ This result was validated in another study, wherein short CNTs were injected subcutaneously in rats and detected in the cytosol of macrophages after 4 weeks; however, the longer CNTs were moving, freely resulting in inflammation. ${ }^{41}$ Intraperitoneal injection of both long and short CNTs in mice has produced similar results. ${ }^{46}$ The nontoxic length affirmed 
for CNTs was $\sim 10 \mu \mathrm{m} .{ }^{47}$ It has been revealed that when CNTs surpass $20 \mu \mathrm{m}$ length, they cannot be phagocytized and could thus exhibit destruction of the plasma membranes in cells, further eliciting greater inflammatory responses.

Thus, with the progress in the field of CNT research, it can be asserted that the biocompatibility of CNTs towards cells relies on various manageable properties, including the size, morphology, the conjugates, and surface modifications of CNTs, which would be able to address the key issue of biosafety of CNTs. Functionalization is a process allowing the conjugation of various molecules of choice onto the surface of CNTs, leading to reduced toxicity. ${ }^{47}$ Functionalization of CNTs has several advantages, including enhanced solubility in water, increased dispersion, and a lower tendency to form agglomerates, resulting in reduced cytotoxicity. ${ }^{48}$

\section{Advantages and applications of functionalized CNTs}

The smooth surface of carbon nanomaterials lacking any overhanging bonds renders them chemically inert and incompatible with almost all organic and inorganic solvents, which further makes them less amenable for manipulation and downstream applications. In order to address this problem, surface modifications or functionalization of nanoparticles could play a crucial role in improving their physicochemical and surface properties. ${ }^{49}$ The overall objective of functionalizing CNTs for biomedical applications is to increase their solubility or dispersion in biocompatible (aqueous) media, thereby reducing toxic effects. It has been reported that after modifications, fCNT solubility increased significantly. ${ }^{50}$ Many studies have shown that increased solubility (or dispersion) of fCNTs improves their performance and lowers their toxicity (Table 1). ${ }^{16,51-53}$ These fCNTs have excellent electro-optical properties, high tensile strength, and a high surface-area-to-volume ratio that facilitates surface functionalization. ${ }^{54}$ The addition of a layer of biocompatible material can be used to annihilate the toxicity of pristine CNT aggregates by making them more dispersible in aqueous solutions. ${ }^{55}$ Functionalization of CNTs can be achieved by using oligonucleotides, biomolecules, surfactants, and polymers, (Figure 1) thus increasing the dispersibility of CNTs and decreasing their cytotoxicity. ${ }^{56-59}$ In a study comparing CNTs dispersed either through functionalization or with the help of a surfactant, it was revealed that fCNTs had low cytotoxicity, whereas the surfactant-dispersed CNTs in turn showed less toxicity than pristine CNTs. ${ }^{17}$ Reports have also shown that the highly water-soluble modified SWCNTs had low agglomeration and were taken up into the cells without distressing cell viability. ${ }^{37}$ Studies have also shown that the cytotoxicity on lung mesothelic cells (MSTO-211H) is linked to the extent of agglomeration, and also that the suspended CNTs had less toxicity. ${ }^{60}$ Subsequently, it has been shown that using fCNTs permits testing with living cells through miscibility in cell culture with satisfactory distribution, with low aggregation and reduced cytotoxicity. ${ }^{47}$

fCNTs display distinctive characteristics that make them more biocompatible with physiological systems, thus decreasing their toxicity compared to CNTs. fCNTs have the capability to infiltrate cell membranes with fairly low toxicity. ${ }^{8,9,25}$ Recent studies have suggested that CNTs could be translocated into cells through insertion and diffusion into the lipid bilayer of the cell membrane and also that water-soluble nanotubes displayed no significant cytotoxicity to living cells. ${ }^{61}$ Surface modifications of the CNTs could alter the surface chemistry, thus changing the interactions with the lipid bilayer and enhancing uptake into the cells. ${ }^{62}$ As reported in several studies carried out in cell cultures, water-soluble fCNTs exhibit no ${ }^{63,64}$ or abridged cytotoxicity and oxidative stress, ${ }^{26,33,42,65}$ compared to CNTs by themselves. CNTs have shown a decrease in toxicity with higher functionalization on their sidewalls. ${ }^{42}$ Cytotoxicity studies on the J774A MOs cell line involving unpurified CNTs (UP-CNTs), purified CNTs (P-CNTs), fluorescein isothiocyanate-conjugated CNTs (FITC-CNTs), and Entamoeba histolytica L220-CNTs showed cytotoxic effects in the order of UP-CNTs > P-CNTs > FITC-CNTs, with a reduction in cell viability and an escalation in apoptosis compared to MOs that were allowed to interact with L220CNTs, with a rise in cell viability without any significant manifestation of apoptosis. UP-CNTs and P-CNTs displayed induction of cyclooxygenase- 2 with $6.0 \mathrm{mg} / \mathrm{L}$. However, fCNTs were able to induce cyclooxygenase- 2 at $0.06-\mathrm{mg} / \mathrm{L}$ concentrations. It is evident from such studies that regardless of the extent of proteins conjugated to CNTs, cytotoxicity has been lowered. Moreover, the expression of cytotoxic behavior is a measure of the purification process as well as the functional groups attached to the CNTs, thereby enabling them to establish cross talk with the cell-surface receptors. ${ }^{34}$ CNTs coated with mucin-like polymers were able to interact with the carbohydrate receptors on the cell surface, offering them a way to interact with the cell surface minus any toxic effect. ${ }^{66}$ Glucosamine-functionalized SWCNTs were able to improve the interactions of the cells with SWCNTs. ${ }^{67}$ A study conducted on HL60 cells using two types of fluorescent CNTs with FITC-CNTs and biotin 
Table I Functionalized carbon nanotubes and reduced cytotoxic effects

\begin{tabular}{|c|c|c|c|c|}
\hline $\begin{array}{l}\text { Functional group } \\
\text { or structure }\end{array}$ & Toxicological studies & Application & Target site & Reference \\
\hline Acid-oxidized SWCNTs & $\begin{array}{l}\text { Apoptosis studies showed no } \\
\text { apparent cell toxicity }\end{array}$ & $\begin{array}{l}\text { Intracellular protein } \\
\text { transporters }\end{array}$ & Mammalian cells & Kam and Dai ${ }^{69}$ \\
\hline $\begin{array}{l}\text { Acid-treated, } \\
\text { water-soluble SWCNTs }\end{array}$ & $\begin{array}{l}\text { No changes in cell viability or } \\
\text { structure in lysosomes and } \\
\text { cytoplasm }\end{array}$ & & $\begin{array}{l}\text { Human monocyte- } \\
\text { derived macrophage cells }\end{array}$ & Porter et $\mathrm{a}^{88}$ \\
\hline Purified COOH-SWCNTs & No cytotoxicity & $\begin{array}{l}\text { Pharmacological } \\
\text { applications }\end{array}$ & Cultured mammalian cells & Wang et $\mathrm{al}^{72}$ \\
\hline $\begin{array}{l}\text { Oxidized ultrashort } \\
\text { SWCNTs }\end{array}$ & Showed no cytotoxic effects & $\begin{array}{l}\text { Intracellular delivery of } \\
\text { oligonucleotide molecules }\end{array}$ & Human macrophages & Crinelli et $\mathrm{a}^{91}$ \\
\hline Amine-terminated CNTs & $\begin{array}{l}\text { Cross cellular membrane } \\
\text { without cytotoxicity }\end{array}$ & $\begin{array}{l}\text { Delivery of amino acids } \\
\text { peptides, nucleic acid, } \\
\text { or drugs }\end{array}$ & & $\begin{array}{l}\text { Pantarotto et } \mathrm{al}^{35,68} \\
\text { Singh et } \mathrm{al}^{106} \\
\text { Liu et al }{ }^{99}\end{array}$ \\
\hline SWCNT-PL-PEG & $\begin{array}{l}\text { Gene silencing with no apparent } \\
\text { cytotoxic effects }\end{array}$ & $\begin{array}{l}\text { SH-small interferingRNA } \\
\text { delivery }\end{array}$ & Human T cells & Liu et $\mathrm{al}^{2}$ \\
\hline SWCNT-PEG-drug & $\begin{array}{l}\text { Decreased reactive oxygen species- } \\
\text { mediated toxicological response } \\
\text { and exhibited less cytotoxicity }\end{array}$ & Drug delivery & Neuronal PCI 2 cells & Zhang et $\mathrm{al}^{10}$ \\
\hline $\begin{array}{l}\text { SWCNT-PEG-cisplatin/ } \\
\text { doxorubicin }\end{array}$ & Remarkable reduction of cytotoxicity & $\begin{array}{l}\text { Drug-delivery and imaging } \\
\text { tool }\end{array}$ & Human cancer cells/mice & $\begin{array}{l}\text { Bottini et } \mathrm{al}^{1 / 8} \\
\text { Bhirde et } \mathrm{al}^{16}\end{array}$ \\
\hline SWCNT-PEG-mAb $\left(\alpha_{v} \beta_{3}\right)$ & $\begin{array}{l}\text { Without harming adjacent } \\
\text { normal cells }\end{array}$ & Cancer-cell targeting & $\alpha_{v} \beta_{3}$-positive U87MG cells & Portney et al ${ }^{119}$ \\
\hline SWCNT-PEG & $\begin{array}{l}\text { Revealed no evidence of toxicity } \\
\text { over } 4 \text { months }\end{array}$ & & Mice & Schipper et $\mathrm{al}^{70}$ \\
\hline MWNT-CS-(PC) & $\begin{array}{l}\text { Chitosan and PC reduced the } \\
\text { cytotoxic effects on normal cells } \\
\text { with specific photo-induced toxicity } \\
\text { towards malignant cells }\end{array}$ & Photothermal therapy & $\begin{array}{l}\text { MCF-7, HepG2 and } \\
\text { L-O2 cell lines }\end{array}$ & Liao and Zhang ${ }^{120}$ \\
\hline $\begin{array}{l}\text { Polyoxylethylene sorbitan } \\
\text { monooleate (PS80) CNTs }\end{array}$ & Suppressed cytotoxicity & & $\begin{array}{l}\text { Human lung mesothelium } \\
\text { cells (MSTO-2II-H) }\end{array}$ & Wick et $a^{60}$ \\
\hline $\begin{array}{l}\text { HMDA-SWCNTs; } \\
\text { PDDA chloride-SWCNTs }\end{array}$ & Negligible cytotoxic effects & $\begin{array}{l}\text { Intracellular delivery } \\
\text { of negatively charged } \\
\text { biomolecules }\end{array}$ & Rat heart cells & Krajcik et al ${ }^{128}$ \\
\hline $\begin{array}{l}\text { SWCNTs with human } \\
\text { serum proteins }\end{array}$ & $\begin{array}{l}\text { Blood proteins altered SWCNT } \\
\text { cellular interaction pathways and } \\
\text { reduced cytotoxicity }\end{array}$ & Biological applications & $\begin{array}{l}\text { Human acute monocytic } \\
\text { leukemia cell lines and } \\
\text { human umbilical vein } \\
\text { endothelial cells }\end{array}$ & Ge et $\mathrm{al}^{13}$ \\
\hline BSA-dispersed SWCNTs & No acute deleterious cellular effects & & $\begin{array}{l}\text { Human mesenchymal } \\
\text { stem cells and HeLa cells }\end{array}$ & Holt et al ${ }^{103}$ \\
\hline Albumin-SWCNTs & $\begin{array}{l}\text { Induced cyclooxygenase- } 2 \text { and } \\
\text { modulating toxicity effects } \\
\text { of SWCNTs }\end{array}$ & & $\begin{array}{l}\text { RAW } 264.7 \text { macrophage } \\
\text { cell lines }\end{array}$ & Dutta et al ${ }^{104}$ \\
\hline $\begin{array}{l}\text { Streptavidin-CNT- } \\
\text { protein conjugates }\end{array}$ & $\begin{array}{l}\text { No cytotoxic effects on adjacent } \\
\text { cells }\end{array}$ & Specific drug delivery & Cancer cells & Balavoine et al ${ }^{100}$ \\
\hline DNA-encased MWCNTs & $\begin{array}{l}\text { Does not exert cytotoxic effect } \\
\text { on lymphocytes }\end{array}$ & $\begin{array}{l}\text { Selective thermal ablation } \\
\text { of malignant tissue in vivo }\end{array}$ & In vivo & Ghosh et al ${ }^{1 / 2}$ \\
\hline Lectin-functionalized CNTs & $\begin{array}{l}\text { Increase in cell viability without signs } \\
\text { of apoptosis }\end{array}$ & Nanovaccine fabrication & $\begin{array}{l}\text { J774A macrophage (MOs) } \\
\text { cell line }\end{array}$ & $\begin{array}{l}\text { Montes- } \\
\text { Fonseca et } \mathrm{al}^{34}\end{array}$ \\
\hline $\begin{array}{l}\text { Fluorescent-CNT-FITC/ } \\
\text { biotin conjugates }\end{array}$ & Reduced cytotoxicity & Delivery systems & HL60 cells & Bianco et $\mathrm{al}^{139}$ \\
\hline Cationic fCNTs & Lowers cytotoxicity in vitro & $\begin{array}{l}\text { Delivery of drugs and } \\
\text { biomolecules }\end{array}$ & $\begin{array}{l}\text { CHO, } 3 \text { T3 fibroblast, } \\
\text { Jurkat, HL60 cell lines }\end{array}$ & Shi Kam et al ${ }^{140}$ \\
\hline
\end{tabular}

Abbrevations: CNTs, carbon nanotubes; fCNTs functionalized carbon nanotubes; SWCNTs, single-walled carbon nanotubes; PL, phospholipid; PEG, poly(ethylene glycol); mAb, monoclonal antibody; MWCNTs, multiwalled carbon nanotubes; CS, chitosan; PC, phycocyanin; CTAB, cetyltrimethylammonium bromide; HMDA, hexamethylenediamine; PDDA, polydiallyldimethylammonium; BSA, bovine serum albumin. 

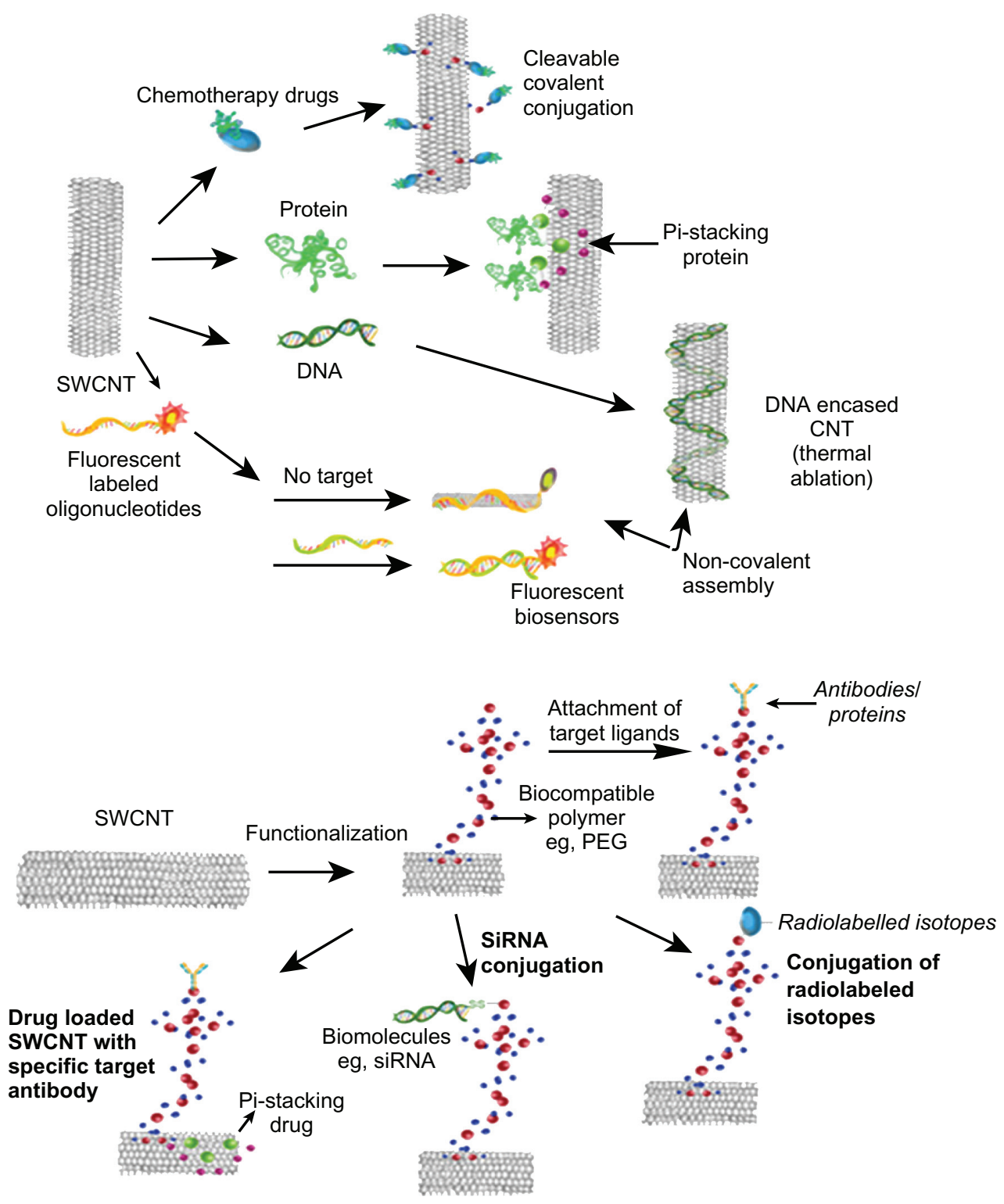

Figure I Overview of functionalization of carbon nanotubes (CNTs) using different molecules and their biomedical applications. Abbreviations: SWCNT, single-walled carbon nanotube; siRNA, small interfering RNA; PEG, polyethylene glycol.

conjugates resulted in enhanced membrane translocation with reduced cytotoxicity, ${ }^{67}$ and another study also indicated the internalization of fluorescently labeled nanotubes into cells with no apparent toxicity. ${ }^{68}$ Similarly, a study conducted on immune-system cells using two classes of fCNTs - one with 1,3-dipolar cycloaddition and another with oxidation/ amidation - showed that both types of fCNTs were taken up by $\mathrm{B}$ and $\mathrm{T}$ lymphocytes as well as by macrophages in vitro without affecting cell viability. ${ }^{63}$ Interestingly, cationic fCNTs have been known to cause much reduced cytotoxicity in vitro, and also functionalized SWCNTs can traverse both nonadherent and adherent cell lines (CHO, 3T3 fibroblast,
Jurkat, HL60) with no toxic effects. ${ }^{69}$ Moreover, when functionalized SWCNTs were injected into the bloodstream of mice, no indication of toxicity was revealed with respect to clinical and laboratory parameters. ${ }^{70}$ In a biodistribution study on mice, functionalized SWCNTs were found in the bone, kidney, and stomach of mice, which would finally be excreted via the renal route, whereas unmodified CNTs were hoarded in the liver, lungs, and spleen, exhibiting toxic effects. ${ }^{63}$ At the same time, functionalized nanorods have discrete effects on cell survival through killing cancer cells and having trivial effect on normal cells and mesenchymal stem cells. ${ }^{5,71,72}$ Thus, the extent of cytotoxicity can directly 
be correlated with their pristine or functionalized nature, and hence it becomes necessary to establish comparatively simpler and more applicable methods for the functionalization of CNTs, making them more water-soluble, biocompatible, noncytotoxic, and optimally biodegradable compounds.

With recent advances in the field of tissue engineering, various biocompatible materials are being devised for various biomedical applications in different tissues, including bone and the cardiovascular system. In order to exploit CNTs as biomaterials for such tissue-regeneration purposes, it is a prerequisite to understand their biocompatibility. CNTs have been reported to be used in preservation of cells, delivery of growth factors or genes, and as scaffolding matrices in order to promote integration with the host tissue. ${ }^{73}$ Furthermore, the functionalization of CNTs can greatly expand their potential applications without causing any side effects. ${ }^{74}$ For tissue regeneration, collagen and polymer fCNT-based matrices (collagen-CNT and polymer-CNT) were used as scaffolds. ${ }^{75,76}$ In another such study, it was found that human mesenchymal stem cells when seeded onto polylactic acid-MWCNT composites could survive and proliferate. ${ }^{77}$ Cell adhesion, viability, and proliferation were also studied on the surface of scaffolds consisting of MWCNTs with chitosan (CS; a biocompatible and biodegradable material) that supported cell growth in vitro. ${ }^{78}$ A novel nanomaterial - nonwoven SWCNTs - was used as cell-growing scaffold in order to study growth behaviors such as adhesion, proliferation, and cytoskeletal development. ${ }^{79}$ It was observed that nonwoven SWCNTs increased cell adhesion and proliferation substantially. Nanocomposites made from MWCNTs and poly(L-lactide) (PLLA) were reported to inhibit the growth of fibroblast cells. ${ }^{80}$ Similarly nanocomposite films based on SWCNTs and poly-D,Llactide-co-glycolide copolymer were processed, and it was found that the biodegradation behavior of the nanocomposites depends on the amount and type of functionalization of CNTs used. ${ }^{81}$ At the same time, MWCNTs modified with polyD,L-lactide were shown to have enhanced polymer stability as compared to poly-D,L-lactide alone, signifying that the implants made from such composites could disperse in vivo relatively slowly. ${ }^{82}$ There have been reports indicating that fCNTs promote the proliferation of osteoblastic cells, ${ }^{74}$ which is a useful characteristic of CNTs when used in biomaterials placed in contact with bone. In vivo studies showing bonetissue compatibility of CNTs and their influence on bone formation showed that MWCNTs were effective in periosteal tissue refurbishment, resulting in slight inflammation in the subperiosteal pocket. It was also reported that the functionalized MWCNTs were unable to elicit a strong inflammatory reactions, with noticeable effects on tissue restoration and bone formation even when placed in contact with it, showing decent tissue and bone compatibility. ${ }^{73,83} \mathrm{CNTs}$ have been studied with respect to their biocompatibility for bones, tissues, and blood for various in vivo applications. ${ }^{84}$ MWCNTs were functionalized with polyurethane for use in cardiovascular applications. ${ }^{85}$ CNTs with oxygen-containing functional groups on the surface enhanced adhesion to the platelets and amended anticoagulation activity, making them better biomaterials for implants for blood-related environments. CNTs functionalized with poly(ethylene glycol) (PEG) have been injected intravenously, and were found to be distributed in various organs with relatively low uptake by the reticuloendothelial system and almost completely cleared from the organs in nearly 2 months with no toxic effects. ${ }^{86}$ Thus, it becomes quintessential in order to exploit the capabilities of CNTs devoid of toxic effect to devise a CNT-based regimen with respect to the functional groups, the process used for it to reduce their cytotoxic effects and improve their biocompatibility.

\section{CNT functionalization methods and their biomedical applications}

CNTs when produced initially are insoluble and less dispersible substances; therefore, it becomes essential to improve their surface properties for enhanced dispersion, solubilization, biocompatibility, and reduced cytotoxicity. Modification of CNT surfaces could elevate their solubility in water, serum, and various solvents for enhancing their biocompatibility, reducing their cytotoxicity in biological systems for biomedical applications. ${ }^{15}$ Biological activities and cytotoxic effects of CNTs are highly dependent on their surface chemistry and the process of their purification and functionalization. We have reviewed various methods that are used for surface modifications of CNTs and their applications in the following sections.

\section{Covalent functionalization}

Solubility and biocompatibility of CNTs are the most imperative factors for their effective use in biomedical applications. Enhanced solubility and reduced toxicity of CNTs could be achieved by purifying the CNTs by covalent functionalization through multistep acid treatment. ${ }^{87}$ The solubility of CNTs can be increased through various methods of purification, which could also expose certain charged groups thereby, reducing cytotoxicity. ${ }^{51}$ Short, acid-oxidized, carboxylated CNTs with hydrophilic surfaces and high 
aqueous dispersions were found to be less toxic and more biocompatible than pristine CNTs in mice. ${ }^{88}$ The uptake of acid-treated, water-soluble SWCNTs was studied using human monocyte-derived macrophage cells, and P-CNTs were found to be inside the lysosomes and cytoplasm without any effects on cell viability or structure compared to UP-CNTs. Similarly, functionalized SWCNTs have been used on cultured mammalian cells, signifying that removal of toxic contaminants related to carboxylated SWCNTs is crucial for the development of carboxylated SWCNTs for pharmacological applications. ${ }^{71}$ Introduction of chemical groups such as $\mathrm{COOH}, \mathrm{OH}$, and $\mathrm{CO}$ increases the $\mathrm{O}_{2}$ content of CNTs, which can also decrease the cytotoxicity of P-CNTs. ${ }^{34,89}$ Oxidized ultrashort SWCNTs have been used as nonviral vectors for the intracellular delivery of oligonucleotide molecules to human macrophages without any cytotoxic effects. ${ }^{90}$ Recently, it was also reported that dispersed SWCNTs are quite benign in terms of cytotoxicity, and also that purified and isolated SWCNTs were unable to cause acute cell death. ${ }^{91}$ It was reported that covalent functionalization of CNTs is a superior method that depends on the degree of functionalization ${ }^{42}$ that augments the biocompatibility of CNTs with lessened cytotoxic effects.

\section{Noncovalent functionalization}

Another method of surface modification of CNTs includes noncovalent functionalization. CNTs are known to noncovalently interact with various molecules through weak interactions such as surface adsorption onto the side walls of CNTs, $\pi-\pi$ stacking, electrostatic interactions, hydrogen bonding, and van der Waals force. Such noncovalent methods increase water miscibility of CNTs, making them less toxic. ${ }^{15}$ Many biomolecules, polymers, and surfactants have been used for the noncovalent functionalization of CNTs to obtain biocompatibility. Porphyrin derivatives and FITCterminated PEG chains have been also coated onto the CNT surface with $\pi-\pi$ interaction between pyrene and the graphitic surface of CNTs, which led to enhanced biocompatibility and reduced toxicity. ${ }^{15}$

\section{Functionalization using protein}

Interactions between proteins and CNTs could play a key role in the biological effects of CNTs. ${ }^{92,93} \mathrm{~A} \pi-\pi$ stacking occurs between CNTs and aromatic residues (Trp, Phe, Tyr) of proteins, enhancing their adsorptivity and biocompatibility, which renders them less toxic as compared to pristine CNTs (Figure 2) ${ }^{13,94,95}$ The CNT-protein nanoconjugates have been found very beneficial in biosensor fabrication, ${ }^{96}$

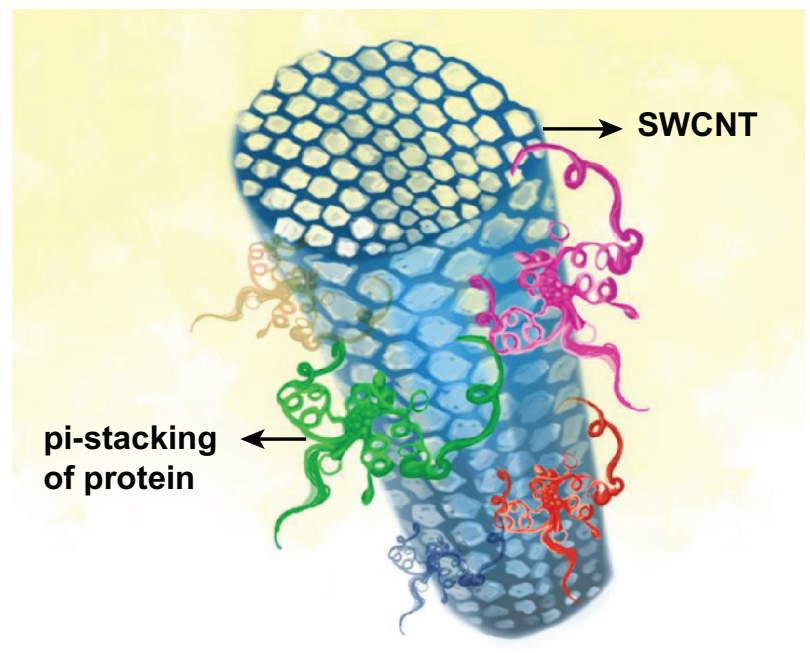

Figure $2 \pi-\pi$ stacking interaction between single-walled carbon nanotube (SWCNT) and protein molecules.

drug delivery, ${ }^{97}$ and cancer therapy. ${ }^{98}$ For example, streptavidin was adsorbed onto the graphitic surface and formed CNT-protein conjugates that were used for cancer therapy, with no cytotoxic effects to the cells in the proximity. ${ }^{99}$ Similarly, CNT-polycarbonate urethane adsorbed with protein fibronectin was reported to have improved cellular activities and tissue growth by demarcating their physical nanoroughness. ${ }^{100}$ A competitive binding of human serum proteins to CNTs was also observed. ${ }^{13}$ Studies on human acute monocytic leukemia cell lines and human umbilical vein endothelial cells have revealed that these blood proteins bind to SWCNT surface, which significantly changes the cellular interaction pathways of the cells, with substantially decreased cytotoxicity. Thus, comparatively safer CNT-based nanomaterials could be devised after understanding their association with the serum protein. ${ }^{13}$

Bovine serum albumin (BSA) is another water-soluble globular protein that adsorbs onto the CNT surface ${ }^{101}$ and gives excellent dispersing capability in vitro. ${ }^{14} \mathrm{BSA}$ dispersed SWCNTs can be uptaken by human mesenchymal stem cells and HeLa cells without significant acute harmful cellular effects. ${ }^{102}$ Similarly, albumin adsorbed onto the surface of SWCNTs can induce cyclooxygenase- 2 in the RAW 264.7 macrophage cell lines, moderating the uptake and cytotoxicity of SWCNTs. ${ }^{103}$ These studies have contributed significantly to the knowledge of biological effects of CNTs at the cellular level. These proteins helped the nanoparticles attain their biological identity, either by diminishing the interactions or altering the cellular machinery. ${ }^{94,104}$ The interaction of proteins (BSA, Tf, BFG, Ig, etc) with CNTs has been shown to affect their uptake, clearance, distribution, 
and delivery to the intended target sites, thus potentially lowering their toxicity. ${ }^{13}$

\section{Functionalization using DNA}

CNTs functionalized with DNA have actually been shown to enhance stability. ${ }^{105,106}$ DNA can bind to SWCNTs, forming tight helices around them, ${ }^{107}$ or can form noncovalent conjugates with CNTs (Figure 3). ${ }^{108}$ CNTs wrapped with flavin mononucleotide and DNA were found to enhance dispersion of these nanotubes. ${ }^{59,109}$ DNA-functionalized CNTs can be used as biological transporters and also as biosensors. ${ }^{110}$ DNA-encased MWCNTs were more effective than plain MWCNTs against malignant tissues when tested in vivo for their thermal ablation capability. ${ }^{111}$ It was further found that DNA-CNTs could penetrate lymphocytes instantaneously with a needle-like mechanism, thus reducing cytotoxic effects. ${ }^{112}$ fCNTs were found to be similar to cellpenetrating proteins, as they can penetrate cells without endocytosis $;{ }^{47}$ however, the internalization of nanomaterials depends on the type of functionalization process.

\section{Functionalization using poly(ethylene glycol)}

Polymers including PEG and PEGylated phospholipids are known for their high biocompatibility and dispersibility, thus making them some of the most efficient surface enhancers for CNTs through noncovalent bonding. ${ }^{3,113,114}$ Several recent studies have found adsorbing phospholipid (PL)-PEG-functionalized CNTs to be noncytotoxic. ${ }^{16,86,115}$ SWCNT-PEGs have displayed relatively lower cytotoxicity in neuronal PC12 cells than uncoated SWCNTs and had decreased reactive oxygen species-mediated toxicological

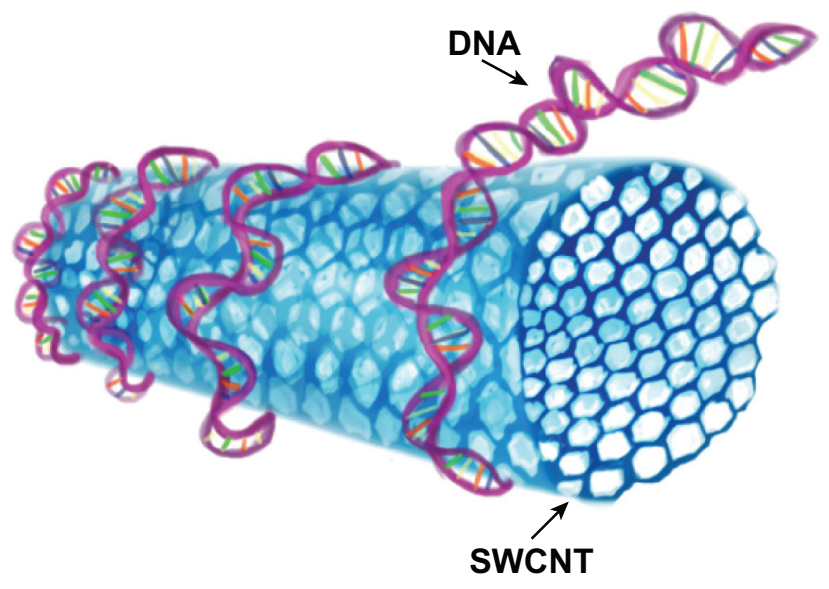

Figure 3 DNA wrap around single-walled carbon nanotubes (SWCNTs) to form tight helices, forming noncovalent conjugates with CNTs. response in vitro, as they have been shown to have less interaction with cell membranes compared to uncoated SWCNTs. ${ }^{10}$ Thus, SWCNT-PEGs are estimated to have impending applications in nanomedicine. ${ }^{15,116}$ SWCNTPEGs are well suited for generation of multifunctional drugs and as imaging tools. ${ }^{117}$ When loaded onto PEGmodified SWCNTs, doxorubicin (DOX), an anticancer drug, exhibited improved therapeutic capability and substantial reduction in cytotoxicity effects compared to the free drug. ${ }^{98}$ Intravenously injected noncovalently functionalized SWCNT-PEGs in mice have revealed no evidence of toxicity. ${ }^{70}$ PL-PEGs having an amine group or a methyl group could make stable aqueous suspensions ${ }^{69}$ and were found to stimulate primary macrophage immune cells ${ }^{118}$ and proinflammatory cytokines in cultures. ${ }^{63}$

\section{Functionalization using chitosan}

CNTs were functionalized using CS, a copolymer of 2-amino2 -deoxy- $\beta$-D-glucopyranose and 2 -acetamido-2-deoxy- $\beta$-Dglucopyranose, through surface adsorption. CS has been the material of choice for CNT functionalization due to its striking water solubility, biocompatibility, biodegradability, nontoxicity, and good complexing ability. Therefore, CS has been widely studied for biomedical and pharmaceutical applications such as drug delivery, cancer therapy, and biosensors. ${ }^{56,119,120}$ CNTs modified with CS are being used for the removal of heavy metals from aqueous solution, ${ }^{122}$ as biomaterials for tissue engineering, ${ }^{123}$ and in delivery of molecules. ${ }^{119}$ A novel biomaterial - MWCNT-CSphycocyanin (PC) - prepared by functionalizing MWCNTs with CS and conjugated to PC (photodynamic therapy and photothermal therapy agent) (Figure 4) for photodynamic and photothermal cancer therapy were tested on breast and liver cancer cell lines (MCF-7 and HepG2) and a normal liver cell line (L-O2). The results revealed that MWCNT-CS-PC showed specific photo-induced toxicity to MCF-7 and HepG2, and the introduction of CS increased solubility. PC reduced the cytotoxicity of the CNT complex on normal cells as well. ${ }^{56}$ SWCNTs modified with biocompatible CS and conjugated to folic acid (FA) (CS-SWCNT-FA) for targeting tumor cells showed that CS could effectively disperse the SWCNTs and provide a suitable biological interface for immobilization of biomolecules. ${ }^{123}$

\section{Functionalization using other polymers}

Block copolymers like poly(L-amino acid), poly(ester), and pluronics have been used for noncovalent functionalization of nanomaterials, having increased dispersibility during 


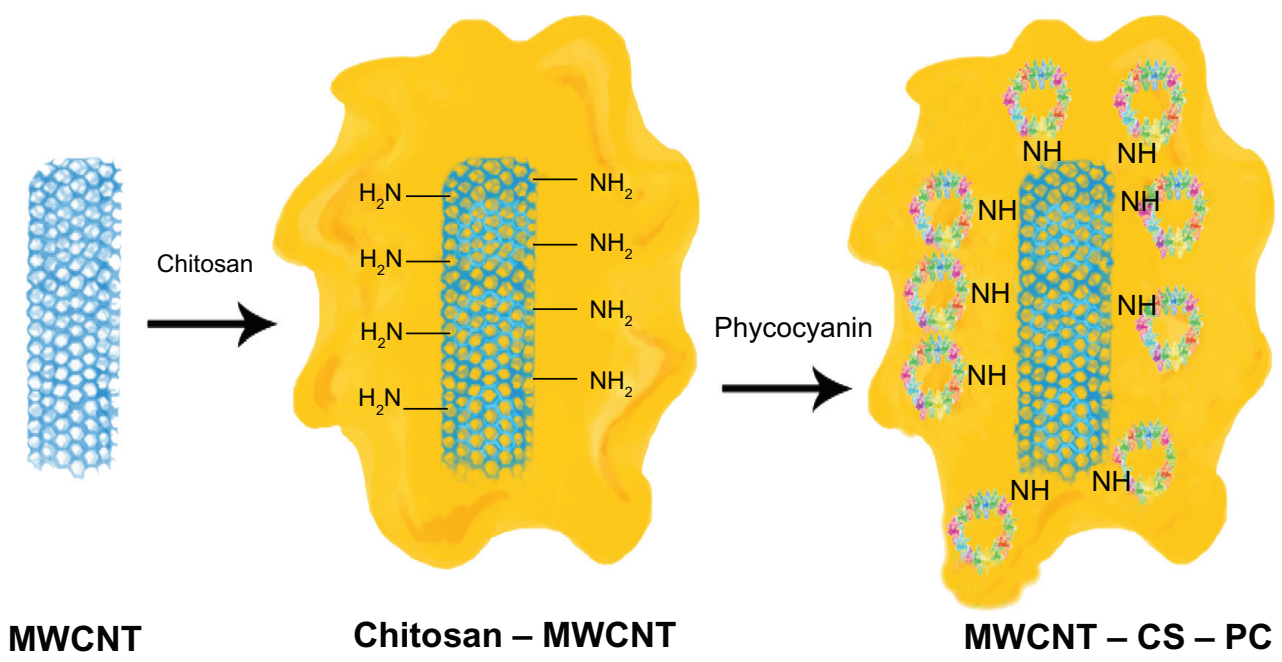

Figure 4 Functionalization of multiwalled carbon nanotube (MWCNT) with chitosan (CS) conjugated to phycocyanin (PC) (photodynamic therapy [PDT] and photothermal therapy [PTT] agent) for PDT and PTT cancer therapy.

drug delivery. ${ }^{124}$ Pluronic F68, a biocompatible linear copolymer of isopropylene glycol repeating units, was found to stabilize aqueous dispersion of SWCNTs. ${ }^{125}$ Moreover, CNT suspensions in two biocompatible dispersants (pluronic F108 and hydroxypropylcellulose), showed no signs of agglomeration and remained dispersed when used in vitro. ${ }^{126}$ Similarly, SWCNTs functionalized with polymers like hexamethylenediamine and poly(diallyldimethylammonium chloride) facilitated noncovalent conjugation for intracellular delivery of negatively charged biomolecules with few cytotoxic effects. ${ }^{127}$ Polymer-functionalized CNTs did not cause cytotoxicity either. ${ }^{63,128}$

\section{Functionalization using surfactants}

Surfactants can enhance the stability and dispersibility of CNTs in the culture medium by absorbing onto the surface of CNTs, thereby reducing cytotoxicity. ${ }^{25}$ Surfactants like sodium dodecyl sulfate, ${ }^{129}$ sodium dodecylbenzenesulfonate, ${ }^{130}$ cetyltrimethylammonium bromide (CTAB), ${ }^{131}$ and the Triton-X series ${ }^{132}$ have been shown to disperse CNTs effectively. Cytotoxicity studies in human umbilical endothelial cells using CTAB-SWCNTs showed that SWCNTs in deionized water had higher cytotoxicity than the SWCNTs in CTAB solution, signifying that the surfactant rendered the CNTs more dispersible in the culture medium and less cytotoxic. ${ }^{25}$ The dispersion of SWCNTs has a significant role in diminishing SWCNT cytotoxicity. ${ }^{15}$ Studies with polyoxylethylene sorbitanmonooleate, a surfactant, also enhanced the dispersibility of CNTs and showed no toxicity to human lung mesothelial (MSTO-211-H) cells. ${ }^{60}$

\section{Multifunctionalization of CNTs}

The physical properties of SWCNTs make them suitable candidates for several biological applications. ${ }^{133-136}$ The delivery of DNA, proteins, or drug molecules into living cells is important for therapeutic purposes. ${ }^{137}$ SWCNTs have been shown to transport various biomolecular cargoes across cellular membrane without cytotoxicity. ${ }^{138-140}$ Several recent studies have demonstrated that CNTs can prove excellent biological vehicles due to their physical properties, without any substantial toxic effects. ${ }^{69}$ SWCNTs functionalized with a folate led to their selective uptake by tumor cells having folate-receptor markers and induced near-infrared radiationtriggered cell death, but not in the normal cells. ${ }^{69}$ PEGylated SWCNTs were attached to FA, which was linked to a Pt (IV) prodrug compound yielding an SWCNT-Pt(IV)-FA conjugate that showed higher toxicity to folate receptorpositive cells but not to folate receptor-negative cells. ${ }^{141}$ SWCNTs functionalized with an arginine-glycine-aspartic acid (RGD) peptide were found to target integrin-positive tumors in mice. ${ }^{142}$

SWCNTs have been known to offer higher surface area when prefunctionalized noncovalently or covalently using general surfactants, polymers or acid-oxidation routes, allowing the attachment of various aromatic molecules, such as anticancer drug (DOX), a fluorescence molecule (fluorescein), and combinations of molecules with very high loading efficiency. ${ }^{145}$ DOX-loaded SWCNTs caused much higher apoptosis and death in U87 cancer cells than free DOX, clearly demonstrating that DOX-loaded SWCNTs were transported inside the cells by nanotube transporters via endocytosis. ${ }^{144}$ SWCNTs have been shown to target drug 
delivery to specific cell types without killing the nontargeted cells. ${ }^{142}$ Prefunctionalized SWCNTs carrying DOX were coupled to a target molecule recognizing target-associated antigens for enhanced selectivity and reduced lethal side effects. ${ }^{145}$ When DOX-loaded SWCNTs were conjugated to cyclic RGD peptide attached to the terminal groups of PEG, the functionalized CNTs were shown to recognize integrin $\alpha v \beta 3$ receptors overexpressed in solid tumors. ${ }^{147}$ RGD-conjugated SWCNTs showed increased DOX delivery and fluorescence signal and caused enhanced cellular uptake and killing in integrin $\alpha v \beta 3$-positive U87MG cells as compared to DOX-loaded SWCNTs without RGD of the SWCNT drug. ${ }^{142}$ PEGylated SWCNTs with RGD peptide and radiolabels (64Cu-DOTA) when intravenously injected into glioblastoma U87MG tumor-bearing mice and examined by micro-positron emission tomography showed elevated tumor uptake when compared to plain SWCNTs without RGD (SWCNT-PEG5400). ${ }^{147}$ In another similar study, integrin $\alpha v \beta 3$ monoclonal antibody conjugated and PL-PEG functionalized SWCNTs were found to have extraordinary targeting efficiency on U87MG cells with reduced cellular toxicity. ${ }^{145}$ Functionalized SWCNTs have shown promising effects in tumor-targeted accretion in mice and demonstrated biocompatibility, excretion, and negligible toxicity. ${ }^{148}$ In vivo SWCNT drug delivery for tumor suppression in mice was performed using paclitaxel (PTX, a cancer chemotherapy drug), conjugated to PEG chains on SWCNTs via an ester bond, resulting in a water-soluble SWCNT-PTX conjugate. SWCNT-PTX showed greater efficacy in subduing the tumor growth compared to taxol (the commercial PTX) in a murine 4T1 breast cancer model, leading to longer blood circulation and higher permeability and retention. Thus, several other similar studies clearly indicate that surface functionalization of SWCNTs is imperative for tumor targeting in vivo ${ }^{147}$ and drug delivery with enhanced efficacy and slightest side effects in cancer therapy with low drug doses. ${ }^{148}$

CNTs have been functionalized with drugs as well as fluorescence labels for in vitro delivery. One such bioconjugate of CNTs conjugated to an anticancer drug ${ }^{97}$ or an antifungal drug ${ }^{149}$ was used for drug delivery into cells. Noncovalently PEGylated SWCNTs were used as a delivery regime to internalize a platinum (IV) complex, a prodrug, against cancer cells. ${ }^{97}$ Targeted intracellular delivery of therapeutic biomolecules is significant, as they do not diffuse through cell membranes easily. ${ }^{147}$ Thus, research has recently been focused on conjugation of these biomolecules, eg, proteins to CNTs through either covalent or noncovalent bonding for intracellular delivery. ${ }^{69,139}$ The hydrophobic surface of partially functionalized SWCNTs (eg, oxidized SWNTs) permits nonspecific binding of proteins. These biomolecules can become active after being internalized and released from endosomes. ${ }^{69}$ CNTs were also modified with positive charges to conjugate plasmids for gene transfection. ${ }^{35,150}$ Polyethylenimine modified MWCNTs were exploited for DNA conjugation and delivery with competitive transfection efficiency to that of standard polyethylenimine transfection with abridged cytotoxicity. ${ }^{106}$ In recent years, knowledge has grown immensely in the field of small interfering RNA (siRNA) technology, and so have their applications in both basic and applied biology. ${ }^{2}$ siRNA linked to PL-PEG-SWCNTs through disulfide bonds effectively brought gene-silencing effects. ${ }^{147}$ Researchers have also been using the functionalization approach, ie, multifunctionalization or using multiple groups such as PEG, drug molecules, proteins, antibodies, or DNA, either simultaneously or sequentially, ${ }^{115}$ making them apt for various biomedical applications.

These studies suggest that functionalization of CNTs elevates their dispersibility, biostability, and reduction in aggregate formation, and reduces cytotoxicity. ${ }^{16}$ Covalent and noncovalent functionalization of CNTs with biomolecules, polymers, copolymers and surfactants are significant practices, leading to the solubility of the CNTs. Moreover, conjugated CNTs can also be used to enhance the biocompatibility and biosafety of CNTs. ${ }^{15}$

\section{Conclusions}

In conclusion, CNTs have been used for various biomedical applications for targeted delivery, anticancer activities, imaging, etc. The cytotoxicity of CNTs has been well addressed through various methods of surface functionalization of CNTs, thereby improving their interaction within biological systems. Given CNTs' relatively lower toxicity, their surface functionalization is a promising strategy for delivering different biological molecules. They are important biomaterials due to their superior characteristics over conventional biomaterials. It is generally agreed that fCNTs constitute a major improvement over unmodified CNTs, since unmodified CNTs often cause adverse reactions to living cells and tissues, whereas fCNTs are less toxic due to more biocompatible functional groups. The most efficient way to transform the surface of CNTs from hydrophobic to hydrophilic is by attaching different water-soluble and functional moieties. Functionalization of CNTs results in highly soluble materials that are further derivatized with active molecules, making them compatible with 
biological systems. Thus, fCNTs possess wider biological applications compared to nonfunctionalized CNTs.

\section{Acknowledgments}

The authors would like to acknowledge grant support from NSF-CREST (HRD-0734232). We also acknowledge Ms Eva Dennis for her assistance in preparing the figures used in this review article.

\section{Disclosure}

The authors report no conflicts of interest in this work.

\section{References}

1. Liu Z, Tabakman S, Li XL, et al. Multiplexed five-color molecular imaging of cancer cells and tumor tissues with carbon nanotube Raman tags in the near-infrared. Nano Res. 2010;3:222-233.

2. Liu Z, Winters M, Holodniy M, Dai H. siRNA delivery into human $\mathrm{T}$ cells and primary cells with carbon-nanotube transporters. Angew Chem Int Ed Engl. 2007;46:2023-2027.

3. Hadidi N, Kobarfard F, Nafissi-Varcheh N, Aboofazeli R. Optimization of single-walled carbon nanotube solubility by noncovalent PEGylation using experimental design methods. Int J Nanomed. 2011;6: $737-746$.

4. Iijima S. Helical microtubules of graphitic carbon. Nature. 1991;354: $56-58$.

5. Liang F, Chen B. A review on biomedical applications of single-walled carbon nanotubes. Curr Med Chem. 2010;17:10-24.

6. Khazaei A, Rad MN, Borazjani MK. Organic functionalization of singlewalled carbon nanotubes (SWCNTs) with some chemotherapeutic agents as a potential method for drug delivery. Int $J$ Nanomedicine. 2010;5:639-645.

7. Khodakovskaya MV, de Silva K, Nedosekin DA, et al. Complex genetic, photothermal, and photoacoustic analysis of nanoparticle-plant interactions. Proc Natl Acad Sci U S A. 2011;108:1028-1033.

8. Mahmood M, Casciano DA, Mocan T, et al. Cytotoxicity and biological effects of functional nanomaterials delivered to various cell lines. JAppl Toxicol. 2010;30:74-83.

9. Zhang Y, Ali SF, Dervishi E, et al. Cytotoxicity effects of graphene and single-wall carbon nanotubes in neural phaeochromocytoma-derived PC12 cells. ACS Nano. 2010;4:3181-3186.

10. Zhang Y, Xu Y, Li Z, et al. Mechanistic toxicity evaluation of uncoated and PEGylated single-walled carbon nanotubes in neuronal PC12 Cells. ACS Nano. 2011;5:7020-7033.

11. Higgins P, Dawson J, Walters M. Nanomedicine: nanotubes reduce stroke damage. Nat Nanotechnol. 2011;26:121-125.

12. Ali-Boucetta H, Al-Jamal KT, Kostarelos K. Cytotoxic assessment of carbon nanotube interaction with cell cultures. Methods Mol Biol. 2011;726:299-312.

13. Ge C, Du J, Zhao L, et al. Binding of blood proteins to carbon nanotubes reduces cytotoxicity. Proc Natl Acad Sci U S A. 2011;108: 16968-16973.

14. Wang X, Xia T, Ntim SA, et al. Quantitative techniques for assessing and controlling the dispersion and biological effects of multiwalled carbon nanotubes in mammalian tissue culture cells. ACS Nano. 2010;4:7241-7252.

15. Yan L, Zhao F, Li S, Hu Z, Zhao Y. Low-toxic and safe nanomaterials by surface-chemical design, carbon nanotubes, fullerenes, metallofullerenes, and graphenes. Nanoscale. 2011;3:362-382.

16. Bhirde AA, Patel S, Sousa AA, et al. Distribution and clearance of PEG-single-walled carbon nanotube cancer drug delivery vehicles in mice. Nanomedicine. 2010;5:1535-1546.
17. Foldvari M, Bagonluri M. Carbon nanotubes as functional excipients for nanomedicines: II. Drug delivery and biocompatibility issues. Nanomedicine. 2008;4:183-200.

18. Maynard AD, Baron PA, Foley M, et al. Exposure to carbon nanotube material: aerosol release during the handling of unrefined single-walled carbon nanotube material. $J$ Toxicol Environ Health A. 2004;67: $87-107$.

19. Tejral G, Panyala NR, Havel J. Carbon nanotubes: toxicological impact on human health and environment. J Appl Biomed. 2009;7:1-13.

20. Pacurari M, Yin XJ, Zhao J, et al. Raw single-wall carbon nanotubes induce oxidative stress and activate MAPKs, AP-1, NF- $\mathrm{kB}$, and Akt in normal and malignant human mesothelial Cells. Environ Health Perspect. 2008;116:1211-1217.

21. Shvedova AA, Pietroiusti A, Fadeel B, Kagan VE. Mechanisms of carbon nanotube-induced toxicity: focus on oxidative stress. Toxicol Appl Pharmacol. 2012;261:121-133.

22. Yuan J, Gao H, Sui J, Duan H, Chen WN, Ching CB. Cytotoxicity evaluation of oxidized single-walled carbon nanotubes and graphene oxide on human hepatoma HepG2 cells: an iTRAQ-coupled 2D LC-MS/ MS proteome analysis. Toxicol Sci. 2012;126:149-161.

23. Yuan J, Gao H, Ching CB. Comparative protein profile of human hepatoma HepG2 cells treated with graphene and single-walled carbon nanotubes: an iTRAQ-coupled 2D LC-MS/MS proteome analysis. Toxicol Lett. 2011;207:213-221.

24. Murray AR, Kisin E, Leonard SS, et al. Oxidative stress and inflammatory response in dermal toxicity of single-walled carbon nanotubes. Toxicology. 2009;257:161-171.

25. Zhang LW, Zeng L, Barron AR, Monteiro-Riviere NA. Biological interaction of functionalized single-wall carbon nanotubes in human epidermal keratinocytes. Int J Toxicol. 2007;26:103-113.

26. Bottini M, Bruckner S, Nika K, et al. Multi-walled carbon nanotubes induce T lymphocyte apoptosis. Toxicol Lett. 2006;160:121-126.

27. Ding L, Stilwell J, Zhang T, et al. Molecular characterization of the cytotoxic mechanism of multiwall carbon nanotubes and nano-onions on human skin fibroblast. Nano Lett. 2005;5:2448-2464.

28. Yan XB, Gu YH, Huang D, et al. Binding tendency with oligonucleotides and cell toxicity of cetyltrimethyl ammonium bromide-coated singlewalled carbon nanotubes. Trans Nonferrous Met Soc China. 2011;21: 1085-1091.

29. Zhao YL, Nalwa HS. Nanotoxicology: Interactions of Nanomaterials with Biological Systems. Los Angeles: American Scientific; 2006.

30. Shvedova A, Castranova V, Kisin E, et al. Exposure to carbon nanotube material: assessment of nanotube cytotoxicity using human keratinocyte cells. J Toxicol Environ Health. 2003;66:1909-1926.

31. Wang X, Jia G, Wang H, et al. Diameter effects on cytotoxicity of multi-walled carbon nanotubes. J Nanosci Nanotechnol. 2009;9: 3025-3033.

32. Cui D, Tian F, Ozkan CS, Wang M, Gao H. Effect of single wall carbon nanotubes on human HEK293 cells. Toxicol Lett. 2005;155:73-85.

33. Monteiro-Riviere NA, Nemanich RJ, Inman AO, Wang YY, Riviere JE. Multi-walled carbon nanotube interactions with human epidermal keratinocytes. Toxicol Lett. 2005;155:377-384.

34. Montes-Fonseca SL, Orrantia-Borunda E, Aguilar-Elguezabal A, González Horta C, Talamás-Rohana P, Sánchez-Ramírez B Cytotoxicity of functionalized carbon nanotubes in J774A macrophages. Nanomedicine. 2012;8:853-859.

35. Pantarotto D, Singh R, McCarthy D, et al. Functionalized carbon nanotubes for plasmid DNA gene delivery. Angew Chem Int Ed Engl. 2004; $43: 5242-5246$.

36. Soto K, Garza KM, Murr LE. Cytotoxic effects of aggregated nanomaterials. Acta Biomater. 2007;3:351-358.

37. Uo M, Akasaka T, Watari F, Sato Y, Tohji K. Toxicity evaluations of various carbon nanomaterials. Dent Mater J. 2011;30: $245-263$.

38. Sayes CM, Liang F, Hudson JL, et al. Functionalization density dependence of single-walled carbon nanotubes cytotoxicity in vitro. Toxicol Lett. 2006;161:135-142. 
39. Lam CW, James JT, McCluskey R, Hunter RL. Pulmonary toxicity of single-wall carbon nanotubes in mice 7 and 90 days after intratracheal instillation. Toxicol Sci. 2004;77:126-134.

40. Carrero-Sánchez JC, Elias AL, Mancilla R, et al. Biocompatibility and toxicological studies of carbon nanotubes doped with nitrogen. Nano Lett. 2006;6:1609-1616.

41. Sato Y, Yokoyama A, Shibata Ki, et al. Influence of length on cytotoxicity of multi-walled carbon nanotubes against human acute monocytic leukemia cell line THP-1 in vitro and subcutaneous tissue of rats in vivo. Mol Biosyst. 2006;1:176-186.

42. Warheit DB, Laurence BR, Reed KL, et al. Comparative pulmonary toxicity assessment of single-wall carbon nanotubes in rats. Toxicol Sci. 2004; 77:117-125

43. Shvedova AA, Kisin ER, Mercer R, et al. Unusual inflammatory and fibrogenic pulmonary responses to single-walled carbon nanotubes in mice. Am J Physiol Lung Cell Mol Physiol. 2005;289:L698-L708.

44. Nel A, Xia T, Mädler L, Li N. Toxic potential of materials at the nanolevel. Science. 2006;311:622-627.

45. Kolosnjaj-Tabi J, Hartman KB, Boudjemaa S, et al. In vivo behavior of large doses of ultrashort and full-length single-walled carbon nanotubes after oral and intraperitoneal administration to Swiss mice. ACS Nano. 2010;4:1481-1492.

46. Poland CA, Duffin R, Kinloch I, et al. Carbon nanotubes introduced into the abdominal cavity of mice show asbestos-like pathogenicity in a pilot study. Nat Nanotechnol. 2008;3:423-428.

47. Firme CP, Bandaru PR. Toxicity issues in the application of carbon nanotubes to biological systems. Nanomedicine. 2010;6:245-256.

48. Coccini T, Roda E, Sarigiannis DA, et al. Effects of water-soluble functionalized multi-walled carbon nanotubes examined by different cytotoxicity methods in human astrocyte D384 and lung A549 cells. Toxicology. 2010;269:41-53.

49. Wu HC, Chang X, Liu L, Zhao F, Zhao Y. Chemistry of carbon nanotubes in biomedical applications. J Mater Chem. 2010;20: 1036-1052.

50. Zhang Y, Bai Y, Yan B. Functionalized carbon nanotubes for potential medicinal applications. Drug Discov Today. 2010;15:428-435.

51. Cui HF, Vashist SK, Al-Rubeaan K, Luong JHT, Sheu FS. Interfacing carbon nanotubes with living mammalian cells and cytotoxicity issues. Chem Res Toxicol. 2010;23:1131-1147.

52. Jiang W, Mardyani S, Fischer H, Chan WCW. Design and characterization of lysine cross-linked mercapto-acid biocompatible quantum dots. Chem Mater. 2006;4:872-881.

53. Veronese FM, Pasut G. PEGylation, successful approach to drug delivery. Drug Discov Today. 2005;10:1451-1458.

54. Kostarelos K, Bianco A, Prato M. Promises, facts and challenges for carbon nanotubes in imaging and therapeutics. Nat Nanotechnol. 2009;4:627-633.

55. Bhirde AA, Liu G, Jin A, et al. Combining portable Raman probes with nanotubes for theranostic applications. Theranostics. 2011;1: 310-321.

56. Liao X, Zhang X. Preparation, characterization and cytotoxicity of carbon nanotube-chitosan-phycocyanin complex. Nanotechnology. $2012 ; 23: 1-13$.

57. Haggenmueller R, Rahatekar SS, Fagan JA, et al. Comparison of the quality of aqueous dispersions of single wall carbon nanotubes using surfactants and biomolecules. Langmuir. 2008;24:5070-5078.

58. Nish A, Hwang JY, Doig J, Nicholas RJ. Highly selective dispersion of single-walled carbon nanotubes using aromatic polymers. Nat Nanotechnol. 2007;2:640-646.

59. Zheng M, Jagota A, Semke ED, et al. DNA-assisted dispersion and separation of carbon nanotubes. Nat Mater. 2003;2:338-342.

60. Wick P, Manser P, Limbach LK, et al. The degree and kind of agglomeration affect carbon nanotube cytotoxicity. Toxicol Lett. 2007; 168:121-131

61. Hirsch A. The era of carbon allotropes. Nat Mater. 2010;9:868-871.

62. Lopez CF, Nielsen SO, Moore PB, Klein ML. Understanding nature's design for a nanosyringe. Proc Nat Acad Sci U S A. 2004;101: 4431-4434.
63. Dumortier H, Lacotte S, Pastorin G, et al. Functionalized carbon nanotubes are non-cytotoxic and preserve the functionality of primary immune cells. Nano Lett. 2006;6:1522-1528.

64. Pantarotto D, Partidos CD, Graff R, et al. Synthesis, structural characterization, and immunological properties of carbon nanotubes functionalized with peptides. J Am Chem Soc. 2003;125:6160-6164.

65. Magrez A, Kasas S, Salicio V, et al. Cellular toxicity of carbon-based nanomaterials. Nano Lett. 2006;6:1121-1125.

66. Chen X, Tam UC, Czlapinski JL, et al. Interfacing carbon nanotubes with cells. J Am Chem Soc. 2006;128:6292-6293.

67. Nimmagadda A, Thurston K, Nollert MU, McFetridge PS. Chemical modification of SWNT alters in vitro cell-SWNT interactions. J Biomed Mater Res A. 2006;76:614-625.

68. Pantarotto D, Briand JP, Prato M, Bianco A. Translocation of bioactive peptides across cell membranes by carbon nanotubes. Chem Commun. 2004; 7:16-17.

69. Kam NWS, Liu Z, Dai H. Functionalization of carbon nanotubes via cleavable disulfide bonds for efficient intracellular delivery of siRNA and potent gene silencing. J Am Chem Soc. 2005;127: 12492-12493.

70. Schipper ML, Nakayama-Ratchford N, Davis CR, et al. A pilot toxicology study of single-walled carbon nanotubes in a small sample of mice. Nat Nanotechnol. 2008;3:216-221.

71. Wang R, Mikoryak C, Li S, et al. Cytotoxicity screening of single-walled carbon nanotubes: detection and removal of cytotoxic contaminants from carboxylated carbon nanotubes. Mol Pharm. 2011;8:1351-1361.

72. Yang D, Zhao Y, Guo H, et al. [Gd@C82(OH)22]n nanoparticles induce dendritic cell maturation and activate Th1 immune responses. ACS Nano. 2010;4:1178-1186.

73. Saito N, Usui Y, Aoki K, et al. Carbon nanotubes: biomaterial applications. Chem Soc Rev. 2009;38:1897-1903.

74. Saito N, Usui Y, Aoki K, et al. Carbon nanotubes for biomaterials in contact with bone. Curr Med Chem. 2008;15:523-527.

75. MacDonald RA, Laurenzi BF, Viswanathan G, Ajayan PM, Stegemann JP. Collagen-carbon nanotube composite materials as scaffolds in tissue engineering. J Biomed Mater Res A. 2005;74:489-496.

76. Cao Y, Zhou YM, Shan Y, Ju HX, Xue XJ. Preparation and characterization of grafted collagen-multiwalled carbon nanotubes composites. J Nanosci Nanotechnol. 2007;7:447-451.

77. McCullen SD, Stevens DR, Roberts WA, et al. Characterization of electrospun nanocomposite scaffolds and biocompatibility with adipose-derived human mesenchymal stem cells. Int J Nanomed. 2007;2:253-263.

78. Abarrategi A, Gutiérrez MC, Moreno-Vicente C, et al. Multiwall carbon nanotube scaffolds for tissue engineering purposes. Biomaterials. 2008;29:94-102.

79. Meng J, Song L, Kong H, et al. Using single-walled carbon nanotubes nonwoven films as scaffolds to enhance long-term cell proliferation in vitro. J Biomed Mater Res A. 2006;79:298-306.

80. Zhang D, Kandadai MA, Cech J, Roth S, Curran SA. Poly (L-lactide) (PLLA)/multiwalled carbon nanotube (MWCNT) composite: characterization and biocompatibility evaluation. J Phys Chem. 2006; 110:12910-12915.

81. Armentano I, Dottori M, Puglia D, Kenny J. Effects of carbon nanotubes (CNTs) on the processing and in-vitro degradation of poly(DL-lactide-coglycolide)/CNT films. J Mater Sci Mater Med. 2008;19:2377-2387.

82. Krul LP, Volozhyn AI, Belov DA, et al. Nanocomposites based on poly-D,L-lactide and multiwall carbon nanotubes. Biomol Eng. 2007;24: 93-95.

83. Usui Y, Aoki K, Narita N, et al. Carbon nanotubes with high bonetissue compatibility and bone-formation acceleration effects. Small. 2008;4:240-246.

84. Murugesan S, Park TJ, Yang H, Mousa S, Linhardt RJ. Blood compatible carbon nanotubes - nano-based neoproteoglycans. Langmuir. 2006;22: 3461-3463.

85. Meng J, Kong H, Xu HY, et al. Improving the blood compatibility of polyurethane using carbon nanotubes as fillers and its implications to cardiovascular surgery. J Biomed Mater Res A. 2005;74:208-214. 
86. Liu Z, Davis C, Cai W, et al. Circulation and long-term fate of functionalized, biocompatible single-walled carbon nanotubes in mice probed by Raman spectroscopy. Proc Natl Acad Sci US A. 2008;105: 1410-1415.

87. Porter AE, Gass M, Bendall JS, et al. Uptake of noncytotoxic acidtreated single-walled carbon nanotubes into the cytoplasm of human macrophage cells. ACS Nano. 2009;3:1485-1492.

88. Jain S, Thakare VS, Das M, et al. Toxicity of multiwalled carbon nanotubes with end defects critically depends on their functionalization density. Chem Res Toxicol. 2011;24:2028-2039.

89. Cheng C, Müller KH, Koziol KKK, et al. Toxicity and imaging of multi-walled carbon nanotubes in human macrophage cells. Biomaterials. 2009;30:4152-4160.

90. Crinelli R, Carloni E, Menotta M, et al. Oxidized ultrashort nanotubes as carbon scaffolds for the construction of cell-penetrating NF- $\kappa \mathrm{B}$ decoy molecules. ACS Nano. 2010;4:2791-2803.

91. Holt BD, Short PA, Rape AD, et al. Carbon nanotubes reorganize actin structures in cells and ex vivo. ACS Nano. 2010;4:4872-4878.

92. Lundqvist M, Stigler J, Elia G, et al. Nanoparticle size and surface properties determine the protein corona with possible implications for biological impacts. Proc Natl Acad Sci US A. 2008;105:14265-14270.

93. Cedervall T, Lynch I, Lindman S, et al. Understanding the nanoparticleprotein corona using methods to quantify exchange rates and affinities of proteins for nanoparticles. Proc Natl Acad Sci USA. 2007; 104:2050-2055.

94. Nel AE, Madler L, Velegol D, et al. Understanding biophysicochemical interactions at the nano-bio interface. Nat Mater. 2009;8:543-557.

95. Shim M, Shi Kam NW, Chen RJ, Li Y, Dai H. Functionalization of carbon nanotubes for biocompatibility and biomolecular recognition Nano Lett. 2002;2:285-288.

96. Zhang L, Zhao GC, Wei XW, Yang ZS. A nitric oxide biosensor based on myoglobin adsorbed on multi-walled carbon nanotubes. Electroanalysis. 2005;17:630-634.

97. Feazell RP, Nakayama-Ratchford N, Dai H, Lippard SJ. Soluble singlewalled carbon nanotubes as longboat delivery systems for platinum (IV) anticancer drug design. J Am Chem Soc. 2007;129:8438-8439.

98. Liu Z, Fan AC, Rakhra K, et al. Supramolecular stacking of doxorubicin on carbon nanotubes for in vivo cancer therapy. Angew Chem Int Ed Engl. 2009;48:7668-7672.

99. Balavoine F, Schultz P, Richard C, et al. Helical crystallization of proteins on carbon nanotubes: a first step towards the development of new biosensors. Angew Chem Int Ed Engl. 1999;38:1912-1915.

100. Khang D, Kim SY, Liu-Snyder P, et al. Enhanced fibronectin adsorption on carbon nanotube/poly(carbonate) urethane: independent role of surface nano-roughness and associated surface energy. Biomaterials. 2007;28:4756-4768.

101. Zhao X, Liu R, Chi Z, Teng Y, Qin P. New insights into the behavior of bovine serum albumin adsorbed onto carbon nanotubes: comprehensive spectroscopic studies. J Phys Chem B. 2010;114:5625-5631.

102. Holt BD, Dahl KN, Islam MF. Quantification of uptake and localization of bovine serum albumin-stabilized single-wall carbon nanotubes in different human cell types. Small. 2011;7:2348-2355.

103. Dutta D, Sundaram SK, Teeguarden JG, et al. Adsorbed proteins influence the biological activity and molecular targeting of nanomaterials. Toxicol Sci. 2007;100:303-315.

104. Lynch I, Dawson KA. Protein-nanoparticle interactions. Nano Today. 2008;3:40-47.

105. Singh R, Pantarotto D, McCarthy D, et al. Binding and condensation of plasmid DNA onto functionalized carbon nanotubes: toward the construction of nanotube-based gene delivery vectors. $\mathrm{J} \mathrm{Am} \mathrm{Chem}$ Soc. 2005; 127:4388-4396.

106. Liu Y, Wu DC, Zhang WD, et al. Polyethylenimine-grafted multiwalled carbon nanotubes for secure noncovalent immobilization and efficient delivery of DNA. Angew Chem Int Ed Engl. 2005;44:4782-4785.

107. Zangmeister RA, Maslar JE, Opdahl A, Tarlov MJ. Adsorption behavior of DNA-wrapped carbon nanotubes on self-assembled monolayer surfaces. Langmuir. 2007;23:6252-6256.
108. Tasis D, Tagmatarchis N, Bianco A, Prato M. Chemistry of carbon nanotubes. Chem Rev. 2006;106:1105-1136.

109. Ju S, Doll J, Sharma I, Papadimitrakopoulos F. Selection of carbon nanotubes with specific chiralities using helical assemblies of flavin mononucleotide. Nat Nanotechnol. 2008;3:356-362.

110. Sánchez-Pomales G, Santiago-Rodríguez L, Cabrera C. DNA-functionalized carbon nanotubes for biosensing applications. J Nanosci Nanotechnol. 2009;9:2175-2188.

111. Ghosh S, Dutta S, Gomes E, et al. Increased heating efficiency and selective thermal ablation of malignant tissue with DNA-encased multiwalled carbon nanotubes. ACS Nano. 2009;3:2667-2673.

112. Cheung W, Pontoriero F, Taratula O, Chen AM, He H. DNA and carbon nanotubes as medicine. Adv Drug Delivery Rev. 2010;62:633-649.

113. Prencipe G, Tabakman SM, Welsher K, et al. PEG branched polymer for functionalization of nanomaterials with ultra long blood circulation. J Am Chem Soc. 2009; 131:4783-4787.

114. Nakayama-Ratchford N, Bangsaruntip S, Sun X, Welsher K, Dai H. Noncovalent functionalization of carbon nanotubes by fluorescein-polyethylene glycol: supramolecular conjugates with $\mathrm{pH}$ dependent absorbance and fluorescence. J Am Chem Soc. 2007;129: 2448-2449

115. Liu Z, Tabakman SM, Chen Z, Dai H. Preparation of carbon nanotube bioconjugates for biomedical applications. Nat Protoc. 2009;4:1372-1381.

116. Li XM, Fan YB, Watari F. Current investigations into carbon nanotubes for biomedical application. Biomed Mater. 2010;5:022001-022012.

117. Bottini M, Rosato N, Bottini N. PEG-modified carbon nanotubes in biomedicine: current status and challenges ahead. Biomacromolecules. 2011;12:3381-3393.

118. Portney N, Ozkan M. Nano-oncology: drug delivery, imaging, and sensing. Anal Bioanal Chem. 2006;384:620-630.

119. Liao XX, Zhang BC, Wang XQ, Yan HD, Zhang XW. Purification of C-phycocyanin from Spirulina platensis by single-step ion-exchange chromatography. Chromatographia. 2011;73:291-296.

120. Kim DG, Jang MJ, Choi CY, Kim TH, Jang MK, Nah JW. Enhance of tumor targeting by receptor-mediated endocytosis using low molecular water-soluble chitosan nanoparticles loaded with anticancer agent. Key Eng Mater. 2007;342-343:469.

121. Salam MA, Makki MSI, Abdelaal MY. Preparation and characterization of multi-walled carbon nanotubes/chitosan nanocomposite and its application for the removal of heavy metals from aqueous solution. J Alloys Compd. 2011;509:2582-2587.

122. Venkatesan J, Qian ZJ, Ryu B, Kumar NA, Kim SK. Preparation and characterization of carbon nanotube-grafted-chitosan - natural hydroxyapatite composite for bone tissue engineering. Carbohydr Polym. 2011;83:569-577.

123. Wu B, Ou Z, Xing D. Functional single-walled carbon nanotubes/ chitosan conjugate for tumor cells targeting. Proc SPIE. 2009;7519: 75190K1-75190K8.

124. Adams ML, Lavasanifar A, Kwon GS. Amphiphilic block copolymers for drug delivery. J Pharm Sci. 2003;92:1343-1355.

125. Anson-Casaos A, Gonzalez-Dominguez JM, Martinez MT. Separation of single-walled carbon nanotubes from graphite by centrifugation in a surfactant or in polymer solutions. Carbon. 2010;48: 2917-2924.

126. Piret JP, Detriche S, Vigneron R, et al. Dispersion of multi-walled carbon nanotubes in biocompatible dispersants. J Nanopart Res. 2010;12: 75-82.

127. Krajcik R, Jung A, Hirsch A, Neuhuber W, Zolk O. Functionalization of carbon nanotubes enables non-covalent binding and intracellular delivery of small interfering RNA for efficient knock-down of genes. Biochem Biophys Res Commun. 2008;369:595-602.

128. Smart S, Cassady A, Lu G, Martin D. The biocompatibility of carbon nanotubes. Carbon. 2006;44:1034-1047.

129. Yu JR, Grossiord N, Koning CE, Loos J. Controlling the dispersion of multi-wall carbon nanotubes in aqueous surfactant solution. Carbon. 2007;45:618-623. 
130. Whitsitte EA, Andrew RB. Silica coated single walled carbon nanotubes. Nano Lett. 2003;3:775-778.

131. Ryabenko AG, Dorofeeva TV, Zvereva GI. UV-VIS-NIR spectroscopy study of sensitivity of single-wall carbon nanotubes to chemical processing and Van-der-Waals SWNT/SWNT interaction. Verification of the SWNT content measurements by absorption spectroscopy. Carbon. 2004;42:1523-1535.

132. Bai Y, Lin D, Wu F, Wang Z, Xing B. Adsorption of Triton X-series surfactants and its role in stabilizing multi-walled carbon nanotube suspensions. Chemosphere. 2010;79:362-367.

133. Alivisatos P. The use of nanocrystals in biological detection. Nat Biotechnol. 2004;22:47-52.

134. Kim S, Lim YT, Soltesz EG, et al. Near-infrared fluorescent type II quantum dots for sentinel lymph node mapping. Nat Biotechnol. 2004; 22:93-97.

135. Cui Y, Wei Q, Park H, Lieber CM. Nanowire nanosensors for highly sensitive and selective detection of biological and chemical species. Science. 2001;293:1289-1292.

136. Chen RJ, Bangsaruntip S, Drouvalakis KA, et al. Noncovalent functionalization of carbon nanotubes for highly specific electronic biosensors. Proc Natl Acad Sci U SA. 2003;100:4984-4989.

137. Henry CM. New wrinkles in drug delivery. Chem Eng News. 2004;82: $37-42$.

138. Bianco A, Kostarelos K, Partidos CD, Prato M. Biomedical applications of functionalized carbon nanotubes. Chem Commun. 2005;5:571-577.

139. Shi Kam NW, Jessop TC, Wender PA, Dai H. Nanotube molecular transporters: internalization of carbon nanotube-protein conjugates into mammalian cells. J Am Chem Soc. 2004;126:6850-6851.
140. Cherukuri P, Bachilo SM, Litovsky SH. Weisman near-infrared fluorescence microscopy of single-walled carbon nanotubes in phagocytic cells. J Am Chem Soc. 2004;126:15638-15639.

141. Dhar S, Liu Z, Thomale J, Dai H, Lippard SJ. Targeted single-wall carbon nanotube-mediated $\mathrm{Pt}(\mathrm{IV})$ prodrug delivery using folate as a homing device. J Am Chem Soc. 2008;130:11467-11476.

142. Liu Z, Cai W, He L, et al. In vivo biodistribution and highly efficient tumour targeting of carbon nanotubes in mice. Nat Nanotechnol. 2007;2: $47-52$.

143. Liu Z, Sun X, Nakayama-Ratchford N, Dai H. Supramolecular chemistry on water-soluble carbon nanotubes for drug loading and delivery. ACS Nano. 2007;1:50-56.

144. Kam NWS, Dai H. Carbon nanotubes as intracellular protein transporters: generality and biological functionality. $\mathrm{JAm}$ Chem Soc. 2005; 127:6021-6026.

145. Ou Z, Wu B, Xing D, et al. Functional single-walled carbon nanotubes based on an integrin $\alpha v \beta 3$ monoclonal antibody for highly efficient cancer cell targeting. Nanotechnology. 2009;105102:1-7.

146. Mizejewski GJ. Role of integrins in cancer: survey of expression patterns. Proc Soc Exp Biol Med. 1999;222:124-138.

147. Liu Z, Tabakman S, Welsher K, Dai H. Carbon nanotubes in biology and medicine: in vitro and in vivo detection, imaging and drug delivery. Nano Res. 2009;2:85-120.

148. Liu Z, Chen K, Davis C, et al. Drug delivery with carbon nanotubes for in vivo cancer treatment. Cancer Res. 2008;68:6652-6660.

149. Gao LZ, Nie L, Wang TH, et al. Carbon nanotube delivery of the GFP gene into mammalian cells. Chembiochem. 2006;7:239-242.

150. Mello CC, Conte D. Revealing the world of RNA interference. Nature. 2004;431:338-342.
International Journal of Nanomedicine

\section{Publish your work in this journal}

The International Journal of Nanomedicine is an international, peerreviewed journal focusing on the application of nanotechnology in diagnostics, therapeutics, and drug delivery systems throughout the biomedical field. This journal is indexed on PubMed Central, MedLine, CAS, SciSearch ${ }^{\circledR}$, Current Contents $₫ /$ Clinical Medicine,

\section{Dovepress}

Journal Citation Reports/Science Edition, EMBase, Scopus and the Elsevier Bibliographic databases. The manuscript management system is completely online and includes a very quick and fair peer-review system, which is all easy to use. Visit http://www.dovepress.com/ testimonials.php to read real quotes from published authors. 